УДК 316.344.23:44

DOI https://doi.org/10.32840/2707-9147.2020.86.9

\author{
В. Л. НІКОЛАСНКО \\ кандидат соціологічних наук, \\ доцент кафедри соціології та політології \\ факультету лінгвістики та соціальних комунікацій \\ Національний авіаційний університет \\ В. С. КОРНІЛОВ \\ кандидат психологічних наук, \\ доцент кафедри соціології та політології \\ факультету лінгвістики та соціальних комунікацій \\ Національний авіаційний університет
}

\title{
ТРАНСПОРТ ЯК ФАКТОР КОНСТРУЮВАННЯ ТА ВІДТВОРЕННЯ ПРОСТОРОВОЇ НЕРІВНОСТІ
}

У статті висвітлено проблеми, пов'язані із транспортом як фактором конструювання та відтворення просторової нерівності.

У статті показано:

- щуо сочіологія транспорту не може залишати поза увагою питання просторової нерівності та суміжних із нею питань;

- щзо розвиток транспортної мережі - один із факторів трансформації географічного (фізичного) простору в соціальний;

- що транспортна мережа стає фактором конструювання нової (нетрадииійної) просторової нерівності та ї̈ відтворення;

- щз просторова нерівність - важливий фактор соиіального контролю;

- що є суперечність між національно-орієнтованою транспортною інфраструктурою та транспортною інфраструктурою, яка розвивається за методами колоніальної політики, адже розподіляе потоки людей $і$ вантажів згідно з потребами колонізаторів тощуо.

Важливо зазначити, що транспорт - один із чинників зв'язку простору/ часу в життєдіяльності людей. А оскільки ичей зв 'язок забезпечується за допомогою технічних засобів, то його сочіальний вимір далеко не завжди проглядається явно. Однак коли швидкість $і$ напрями переміщення людей і вантажів розглянути під кутом зору ринкових реалій, то виявиться, щчо тепер вони багато в чому залежать не стільки від культурних потреб населення, $a$ скільки від вимог конкуренції, коли прагнення до підвищення швидкості пересування в покритому транспортною мережею просторі стає засобом завоювання конкурентних переваг.

Отже, покриття транспортною мережею тих чи інших географічних просторів визначається не абстрактними потребами ринку, а потребами тих сочіально-економічних суб' сктів, які прагнуть максимального скорочення витрат, часто незважаючи на можливі сочіальні збитки. Тому не дивно, що, наприклад, у колонізованих краӥнах транспортна мережа стала одним із

(c) В. Л. Ніколаєнко, В. С. Корнілов, 2020 
найважливіших засобів конструювання та відтворення просторової нерівності тодi, як питання колоніальної політики поступово зникають із наукового $\check{u}$, зокрема, сочіологічного дискурсу у вітчизняній сочіологіï, незважаючи на реальні практики колонізації чужого життєвого простору.

Ключові слова: транспорт, сочіологія транспорту, фізичний простір, географічний простір, сочіальний простір, фізичний час, сочіальний час, сочіальні нерівності, колоніальна транспортна інфраструктура, колонізація життєвого світу, транспортний колоніалізм.

Постановка проблеми. Не можна не помітити, що в сучасній суспільній свідомості починає домінувати ілюзія втрати актуальності того, що називається колоніальною політикою та іï соціальними наслідками, наприклад, у транспортній сфері. А якщо вона й обговорюється, то переважно в політичному, а не в соціологічному дискурсі. 3 огляду на сказане робимо висновок, що соціологія транспорту має, крім усього іншого, досліджувати й соціальні функції транспорту та їх практичну реалізацію методами колоніальної політики. Отже, $\epsilon$ потреба розглянути: транспорт як фактор трансформації географічного простору в соціальний; як засіб конструювання та відтворення просторової нерівності на колонізованих географічних просторах i, насамкінець, як засіб соціальної диференціації та контролю. Такий підхід дає можливості показати, що колонізація (приватизація) чужого життєвого простору не зникає разом із колоніальною системою, колоніалізм просто змінює свої форми.

Отже, проблема полягає в необхідності вийти за межі наявного знання про колоніалізм як систему практик політичного та економічного панування й подивитися на нього через соціологію транспорту, що, крім усього іншого, має ще звернути увагу й на структурні зміни в колонізованих країнах, котрі відбуваються під впливом відповідної розбудови транспортної мережі.

Аналіз останніх досліджень і публікацій. Наразі немає фундаментальних праць із питань впливу транспортної інфраструктури, яка розвивається, на зміни в соціальних структурах суспільства. До того ж через ті тенденції, що склались в останні декілька десятиліть, питання колоніалізму та неоколоніалізму поступово випадають 3 уваги соціологічного мейнстріму. Навіть у працях представників світ-системного аналізу (наприклад, Самір Амін [1]) хоча й піднімаються зазначені питання, але транспортна проблематика практично не обговорюється.

Провідним для нас стало поняття «колонізація життєвого світу», запропоноване Ю. Габермасом [2]. Воно означає культурну колонізацію, що неодмінно супроводжує будь-яку колоніальну політику, включно із транспортною. Згідно з Габермасом, колонізація життєвого світу відбувається шляхом фрагментації свідомості, яка втрачає спроможність до просвіти. Ми ж наголошуємо, що зазначена фрагментація свідомості базується на фрагментації життєвого простору, що відбувається й методами транспортної політики. Отже, колонізація життєвого 
світу охоплює культурні, економічні, політичні, транспортні та всі інші можливі засоби колонізації. Вона означає не тільки захоплення світовою ринковою (капіталістичною) системою життєвого світу периферійних країн та аборигенних народів, а й захоплення життєвого світу навіть мешканців метрополій, і передусім соціальних низів.

Треба зазначити, що в західних країнах можна знайти низку праць щодо проблем колонізації чужих країн та ролі транспорту в цій справі, що написані не соціологами, а фахівцями з інших дисциплін: економістами, представниками політичної та економічної географії, соціо-економічної історії тощо.

Так, у книзі Е. Галеано «Розтин вен Латинської Америки: п’ять століть розграбування континенту» в розділі «Роль позик і залізниць у деформації економіки Латинської Америки» [3] знаходимо опис негативних наслідків тривалої колоніальної транспортної політики на теренах Латинської Америки.

Залізні дороги за Галеано не склали мережу, котра зв'язала між собою внутрішні райони країн Латинської Америки, і не сприяли становленню та розвитку внутрішнього ринку, а зв'язували центри виробництва $з$ портами. I тому продукти виробництва країн Латинської Америки, не споживались мешканцями колоній, а вивозились у метрополії.

Також він зазначає: «Поява залізниці викликала розпад сформованої структури населення, зайнятого в сільському господарстві, що призвело до занепаду землеробства і скотарства, оголило пасовища, знищило лісозахисні смуги, внаслідок чого місцевість обезлюділа» [3]. А передача територій у концесію "Brazil Railway Company”, «обернулась підпалом хатин і вбивством або вигнанням селянських сімей, які проживали на них» [3].

Про схожі процеси, але вже на теренах Африки, пишуть європейські та африканські автори. Наприклад, такі, як Джина Портер [4], Роберто Бонфатті та Стівен Поелхекке [5], Ремі Джедваб, Едвард Кербі та Александер Мораді [6], Ібрагім Халіл Абдуссалам [7], Шеху Тіджані Юсуф [8], Нвачукву Обіакор та Абуома Агаджелу [9], Барбара Нтомбі Нгвенья [10], та інші.

У центрі уваги цих праць ідеться переважно про зв'язок виробництва, торгівлі та транспортної мережі за умов здійснення колоніальної політики, що вступає у глибоку суперечність із життєвим світом аборигенних народів.

Мета статті. Головною метою цієї роботи є виявити об'єктивну логіку трансформації географічного простору в соціальний, де розбудова транспортної мережі стає фактором конструювання та відтворення нової просторової нерівності, й показати, що це відбувається у випадках, коли вона створюється не у згоді з уявленнями аборигенного населення про простір його проживання, а, отже, й не у згоді з його культурними потребами, а у згоді з уявленнями колонізаторів про раці- 
ональне освоєння нового для них простору як простору вияву їх соціальної, а вужче - виробничої активності, орієнтованої на збагачення.

Виклад основного матеріалу. В колишніх колоніях усе більше друкується праць щодо того, що транспортна інфраструктура, розбудована в колоніальні часи, залишається фактором соціальної диференціації, контролю та відтворення їх у часі. Вони також звертають увагу на те, що транспортна інфраструктура в ринкових суспільствах багато в чому нагадує собою колоніальну. Цей факт став підставою для введення Дароном Асемоглу та Джеймсом Робінсоном у науковий обіг понять «історичні колоніальні інститути» та «колоніальна спадщина» [11]. Виходить, що стара колоніальна залежність перетворилась у неоколоніальну, в якій значну роль відіграє і транспортна залежність, яку можна назвати транспортним колоніалізмом.

Справа в тому, що, наприклад, свобода пересування завжди була запорукою особистої свободи. Однак сама можливість пересування за допомогою транспортних засобів уже пов'язана із правом на пересування хоча б тому, що треба купити квиток. Отже, свобода пересування щось більше, ніж право на пересування. Вона може як передбачати зняття статусних відмінностей у праві на пересування, так і розмежовувати людей на групи, наприклад, за ознакою простору їх перебування в одному й тому ж транспортному засобі, що, як правило, лише закріпляє їх неоднакове становище в соціальних структурах. Чому так? Тому, що це розмежування і є емпіричним показником наявності соціальної структури права на ту чи іншу ступінь свободи пересування, а отже, й показником давно сформованої просторової нерівності, яка виявляє себе не лише на транспорті, а й формі, палаців та хатин, котеджних селищ, спальних районів і нетрів тощо.

Якщо так, то принцип «закон один для всіх»- не більше ніж міф, ідеологема, яка розкриває відомі положення про те, що право як форма суспільної свідомості не більше ніж одна з ідеологій, а право як соціальний інститут - один із засобів охорони конституйованого порядку як системи соціальних нерівностей.

Саме право як інститут захищає право на привілейоване перебування у просторі (включно із простором транспортного засобу) одних груп людей та обмежує у праві на перебування у просторі інших груп людей. Одним воно дозволяє освоювати простір відповідно до власних інтересів, а інших обмежує в такому праві, адже далеко не завжди забезпечено.

Так, у гостросюжетному художньому фільмі режисера Ектора Олівера під назвою «Ніч олівців» (1986), знятому на основі достовірних фактів, розповідається про боротьбу аргентинських студентів за право на безкоштовний проїзний квиток у міському транспорті, що для багатьох активістів закінчилось досить драматично.

Відомо, що залізниці - результат розвитку промисловості й військової справи, що вимагало й вимагає швидкого й масового перекидання 
військ і техніки на великі відстані. Швидкісні залізниці виникають із тієї ж причини, оскільки сам процес виробництва давно став галуззю військової справи. Це породжує суперечності між прагненням до моноnолізацї̈, яка відкриває шлях до концентрації капіталу й супроводжується скороченням витрат на конкуренцію, та необхідністю націоналізації транспорту як засобу зміцнення держави. Приватний власник, як бачимо, вступає в конфлікт із його ж власною державою й не так уже й рідко знаходить засоби контролю над державними органами і тим отримує конкурентні переваги над іншими приватними власниками.

Саме військова справа примушує державу до одержавлення основного транспорту у країні, тоді як приватні компанії прагнуть до безумовного контролю над транспортною мережею, яка знижує, як уже було сказано, транспортні витрати.

Принцип «час - гроші» основоположний у ринкових умовах. Саме він визначає не тільки економічну, але й соціальну поведінку так званих підприємців. Він же є основним у мілітаризації їх свідомості й навіть промисловості. Тому тепер війни найчастіше йдуть не між державами, а між корпораціями, хоча нерідко втягують у них держави. Для прикладу можна згадати документальний фільм американського режисера Роберта Грінвальда «Ірак на продаж: ті, хто збагачуються на війні» (Iraq for Sale: The War Profiteers. 2006), де показано, як американські транснаціональні корпорації (Halliburton, Titan, CACI, KBR тощо) зініціювали війну та досі наживаються на ній.

Категорія транспорту - найбільш загальне поняття про будьякі способи переміщення у просторі людей $і$ вантажів за допомогою технічних засобів. Соціологічна ж інтерпретація цієї категорії полягає в тому, щоби виявити те, яким чином переміщення у просторі людей і вантажів за допомогою технічних засобів впливає на суспільні відносини, наприклад, чи сприяє соціальній консолідації, чи, навпаки, розбиває населення на різностатусні групи.

Отже, соціологічна інтерпретація категорії транспорту передбачає, перш за все, аналіз того, яким чином географічний простір (він же й фізичний, тільки прив'язаний до ландшафту) трансформується в соціальний, а водночас яким чином фізичний час користуванням транспортом теж трансформується в соціальний. А це простір, у якому ми відчуваємо себе високо- або низькостатусними особами не лише протягом відповідного часу, а протягом усього нашого життя, що, зрозуміло, не може не впливати на психічну та когнітивну сферу кожного 3 нас.

Якщо ж розглядати проблему транспорту в категоріях ринкової політичної економії, то виявиться, що зв’язок простору/часу, який забезпечується за допомогою технічних засобів, має не настільки явний соціальний вимір, адже швидкість переміщення й напрями переміщення людей і вантажів тепер будуть залежати не стільки від культурних потреб населення, котре проживає на тій чи іншій географічній території, а чинником конкуренції, тобто прагненням до підви- 
щення швидкості завоювання переваг в освоєнні покритого транспортною мережею простору. До того ж навіть якщо говорити про культурні потреби населення, вони також формуються так званою культурною індустрією. Наприклад, туристичні маршрути створюються фірмами та затверджуються державою, скажімо, під час отримання ліцензії на підприємницьку діяльність.

Швидкість же, як ми знаємо з фізики, - векторна фізична величина, що характеризує швидкість переміщення й напрям руху матеріальної точки відносно обраної системи відліку.

Фізика, звісно, не бере до уваги соціальні чинники, від яких залежить вибір системи відліку. В ринкових умовах основною точкою відліку є орієнтація на перемогу в конкуренції, тому що означає, що покриття транспортною мережею тих чи інших географічних просторів визначається не абстрактними потребами ринку, а потребами тих соціально-економічних суб'єктів, які прагнуть до максимального скорочення витрат, навіть незважаючи на можливі соціальні збитки.

Інакше кажучи, транспортна мережа, що створюється в ринкових умовах, нагадує собою освоєння завойованих просторів колонізаторами, яка не має нічого спільного із принципом свободи освоєння простору проживання та пересування в ньому простих людей.

Ми звикли до того, що, коли говорять про розвиток транспорту, неодмінно пов'язують його з розвитком пасажиропотоку, вантажообігу i, зрозуміло, торгівлі. Але чи так уже все це однозначно в соціальному відношенні?

Ось що писав 3 цього приводу К. Маркс у листі до М.Ф. Данієльсона. Читаємо: «Взагалі, залізниці дали, звичайно, величезний поштовх розвитку зовнішньої торгівлі; але у країнах, котрі вивозять головним чином сировину, ця торгівля посилила злидні народних мас; і до того ж не тільки тому, що тягар нової заборгованості, взятий на себе урядами через залізниці, збільшило тиск податкового пресу на народні маси, але ще й тому, що 3 того моменту, як будь-який продукт місцевого виробництва отримав можливість перетворюватись у космополітичне золото, багато товарів, що були раніше дешевими через відсутність широкого збуту, як, наприклад, фрукти, вино, риба, дичина тощо, стали дорогими і були, таким чином, вилучені з ужитку народу. Водночас, 3 іншого боку, і саме виробництво - я маю на увазі деякі спеціальні види продукції - також змінилось залежно від більшої чи меншої придатності цієї продукції для вивезення, тоді як раніше воно пристосовувалось переважно для місцевого споживання» [12, с. 292].

Вище вже зазначалось, що сьогодні вчені колишніх країн-колоній багато пишуть про транспорт як засіб соціального контролю, про те, що він багато в чому був і залишається інститутом зміцнення залежності від колишніх метрополій, про колоніальну політичну економію, в якій проблемі транспорту належить провідна роль тощо [7].

Простіше кажучи, зростання вантажообігу й розвиток торгівлі зовсім не означає автоматичне поліпшення життя мільйонів людей, 
адже мета такого розвитку полягає в чомусь іншому, а саме - у зростанні прибутків завдяки цим мільйонам, включно із правом визначати спосіб проживання й переміщення мільйонів у покритих транспортною мережею просторів, що й має досліджуватися соціологією транспорту.

Отже те, що ми звикли називати розвитком транспортної мережі, насправді не настільки однозначно в соціальному плані.

Колонізатори освоювали колонізований географічний простір методом будівництва автомобільних доріг та залізниць (а пізніше й авіамаршрутів) в орієнтації на свої потреби, а не 3 тим, щоб допомогти аборигенному населенню освоїти найкращим чином простір їх проживання. Навпаки, вони робили все для того, щоб ускладнити для місцевих людей робити те ж саме.

Тож виходить, що така колонізація означала фактичне привласнення цього простору і трансформацію його у простір соціальний, на якому тепер проживають свої та цужі, вороже налаштовані одні до інших. Причому аборигенне населення стало чужним на власній землі. Паралельно й час фізичного життя колонізаторів та колонізованих став набувати соціального забарвлення, адже колонізовані залишалися приреченими жити спогадами про доколоніальний час, а колонізатори, відповідно, стали жити думками про забезпечення свого домінуючого положення й тому мали забезпечувати його інфраструктурно.

Найяскравіший прикладом колоніальної політики розбудови транспортної інфраструктури є американська політика зв'язування залізничною мережею берегів Атлантичного та Тихого океанів, прокладеною через прерії, не просто ігноруючи інтереси індіанців, але і шляхом їх прямого геноциду.

Те саме стосується й колоніальної політики розбудови промислової інфраструктури, об'єднаної транспортною мережею, під гаслами створення робочих місць. Але тим самим місцеве населення, відповідно, змушене було заглибитись у себе і в цьому стані перебуває досі. В таких умовах неодмінно виникають колаборанти - етнічні родичі, орієнтовані на чужу культуру. Прикладом є, скажімо, індіанська поліція в індіанських резерваціях.

Не секрет, що відсутність залізниць стримує економічний розвиток. Але чи таке вже і благо залізниці, коли вони побудовані не для вільного пересування аборигенних народів, не для розвитку їх культури та зростання добробуту, а для безупинного пограбування країни-колонії шляхом вивезення сировини, корисних копалин, харчових продуктів, культурних цінностей тощо?

Щоправда, у разі зі США, на відміну, наприклад, від Африки, спостерігалося дещо інше. Тут колонізація чужого географічного простору відбувалась, так би мовити, на віки й тому торгівля переважно з Свропою розвивалась з огляду на більш ефективну колонізацію прерій. Бенефеціари від колонізації Африки, як правило, проживали в метрополіях. 
Скажімо, Ремі Джедвеб, Едвард Кербі та Олександр Мораді вивчаючи, як колоніальні залізниці визначили економічну географію Африки, виявили три основні мотиви, якими керувалися колонізатори.

1. Воєнне домінування: лінії були побудовані для здійснення «ефективного контролю» в «Боротьбі за Африку» або для швидкого пересування військ із метою силового контролю над місцевим населенням.

2. Добуток корисних копалин: лінії були побудовані для транспортування здобутих корисних копалин від шахт до портів.

3. Торгівля сільськогосподарською продукцією: лінії були побудовані для з'єднання сільськогосподарських районів у єдину економічну систему [6].

Намагаючись укладати якомога менше коштів, колонізатори мали за намір отримати якомога більший прибуток.

Якщо говорити про військове домінування, то можна згадати про «війну» двох залізничних панафриканських проєктів: британського та французького.

Британський проєкт, запропонований Сесілом Джоном Родсом, передбачав побудову залізниці через усю Африку з півдня на північ: від Кейптауну до Каїру. Французький проєкт передбачав побудову залізниці через усю Африку із заходу на схід від Сенегалу до Джибуті. Обидва проєкти передбачали необхідність військового контролю над південним Суданом. У крайньому разі ця конкуренція між двома колоніальними імперіями призвела до Фашодської кризи (1898 р.), а пізніше - до дипломатичної поразки Франції. Але Велика Британія, навіть одержавши перемогу, так і не змогла повністю завершити свій проєкт.

Щодо використання залізних доріг для придушення повстань корінного африканського населення, можна згадати про повстання племен гереро й нама (1904-1907 рр.) в Намібії проти німецької колоніальної адміністрації, у процесі якого німецькі колонізатори широко використовували вузькоколійні військово-польові залізні дороги для транспортування й забезпечення військ.

Щодо другого мотиву, можна згадати статтю Р. Бонфатті та С. Поелхекке під красномовною назвою «Від шахти до узбережжя: інфраструктура та напрям торгівлі в залежних країнах», у якій уже в анотації написано, що в колишніх колоніях транспортна інфраструктура пов'язує шахти безпосередньо 3 узбережжям, оскільки вона «спочатку була покликана сприяти експорту природних ресурсів у колоніальні часи», тобто, «на користь закордонної торгівлі й на шкоду торгівлі із сусідами та регіональній інтеграції». Така «економічна спадщина колоніалізму» сприяє «сплеску китайських інвестицій в інфраструктуру» [5] цих країн. Фактично вони говорять про нову, тепер уже китайську, а не євро-американську колонізацію Африки.

Щодо третього мотиву можна згадати дослідження боротьби між державами-колонізаторами за сировинні ресурси Африки, проведене А.М. Андрєєвим та Н.Р. Кельчевською. Читаємо: «Протягом першої половини ХХ століття Франція й Великобританія прискорювали коло- 
ніальний розвиток африканських територій. Європейські держави почали активно експлуатувати сільськогосподарські ресурси африканських країн, формувати плантації, тим самим сприяючи переміщенню трудових ресурсів у регіоні. Фактично європейські метрополії створили в Африці перекручену структуру сільського господарства: воно було розподілене на дві складники - експортну, для вивезення до Свропи так званих “колоніальних товарів”, і внутрішню - для забезпечення продовольством місцевого населення» [13].

Усі три вищезазначені мотиви тією чи іншою мірою зберігають свою актуальність і в постколоніальній Африці. Так, гайанський історик і соціолог панафриканіст Уолтер Родні пише: «Допоки іноземці володіють землею, шахтами, фабриками, банками, страховими компаніями, транспортними засобами, газетами, електростанціями тощо, доти багатство Африки перетікатиме в руки цих елементів. Інакше кажучи, за відсутності прямого політичного контролю іноземні інвестиції гарантують, що природні ресурси та праця Африки приноситимуть економічну цінність, яка втрачатиметься для континенту» [14].

І такий процес стосується не лише країн Африки, а і всіх країн периферійного капіталізму. Треба зазначити, що неоколоніальна тенденція панує навіть у нинішній Європі.

Після приєднання країн Східної Європи до Євросоюзу вся їхня важка промисловість (заводи, фабрики, електростанції тощо) й навіть крупне сільське господарство значно занепали, а то й були знищені, тим самим вони перетворились у сировинний придаток Старої Свропи, а також у місце збуту сільськогосподарської продукції та промислових виробів. Таким чином, у країнах Східної Свропи поступово почала деградувати стара залізнична інфраструктура, котра була побудована для обслуговування важкої промисловості, сільського господарства й була важливим фактором соціально-економічного та культурного розвитку. Але деякі нові члени Євросоюзу й самі почали себе відчувати кимось на кшталт колонізаторів не лише щодо країн щце не приєднаних до Свросоюзу, а й приєднаних.

Інакше кажучи, транспорт, розглянутий у найзагальнішому його визначенні - це час, який інституціоналізований у правилах організації та засобах переміщення людей у фізичному просторі. Зазначені правила й засоби, як декларується, створені людьми і для людей, хоча насправді вони створені капіталістами, в інтересах капіталістів, тому примушують звичайних людей, підкорятись зазначеним правилам.

Як бачимо, фізичний простір та, відповідно, фізичний час, постійно обертаються в соціальний простір і соціальний час. Тому питання пересування у просторі/часі, розглядуване під цим кутом зору, показує, що люди нерівні, що вони займають різне соціальне становище, користуються якісно різними засобами пересування й навіть у якійсь мірі пересуваються різними швидкостями й різноспрямованими векторами.

Причиною такого стану є соціальна структура суспільства й положення кожного в ній, а не якась міфічна доля. Саме внаслідок соціаль- 
ного положення хтось постійно літає літаком, а хтось може собі дозволити лише користування маршрутним автобусом. Навіть перебування на одному кораблі або літаку людей із різними статусами не говорить про те, що вони в якомусь сенсі зрівняні за своїми статусами, адже одні 3 них перебувають у люксі або бізнес класі, а інші - в економ-класі. I якщо з якоїсь причини вони виявляються не у своєму оточенні, їх перебування там стає дуже некомфортним. А це вже перехід соціальної нерівності на психічний рівень, на рівень емоційної нерівності та на рівень нерівності вражень. Можна навести приклади мобільної диференціації з індійських реалій, коли багатії їздять з усім комфортом в окремому вагоні, а величезна кількість найбідніших їде на даху інших вагонів. Одні відчувають себе господарями життя, а інші, відповідно, соціальними вигнанцями.

Купуючи квиток, ви обираєте собі той спосіб пересування, який ви можете собі дозволити, і тим уже, - як пасажир, - включаєтесь у справу легітимації соціальної диференціації, не розуміючи, що ціна квитка - показник вашої соціальної ваги й засіб соціального контролю, здійснюваного вами ж самими над вашою ж мобільною поведінкою.

Висновки і пропозиції. Як бачимо, якщо ми виявимо зв'язок переміщення людей у фізичному просторі/часі за допомогою транспортних засобів із соціальними статусами, то простір і час у момент знаходять безліч соціальних характеристик.

Соціальний час, як виявляється, - явище, похідне від статусного характеру освоєння простору, що негайно переходить і на статусне перебування кожного в часі, в якому настільки розрекламована свобода пересування - не більше ніж банальний міф.

Отже, і проблема соціальної справедливості тісно пов'язана 3 фізичним відчуттям та психічним переживанням наявної часовопросторової несправедливості: вона - щось більш вагоме, ніж це прийнято вважати соціологами, а транспортна проблема в її розв'язанні - не остання.

Усе сказане вище й дає підстави стверджувати, що транспортна інфраструктура $є$ вагомим фактором конструювання та відтворення просторової нерівності в суспільствах із ринковою економікою.

Як бачимо, проблеми, що виникли у світі разом із активною колоніальною політикою, не пішли в історичне небуття, а багато в чому визначають історичне обличчя сучасного світу. Це означає, що соціологи не мають права замовчувати ці проблеми, а повинні шукати способи їх розв'язання.

\section{Список використаної літератури}

1. Амин С. Африка жизнь на грани. URL: https://scepsis.net/library/id_486.html

2. Хабермас Ю. Отношения между системой и жизненным миром в условиях позднего капитализма. URL: https://igiti.hse.ru/data/159/314/1234/2_2_2Haber.pdf

3. Галеано Э. Вскрытые вены Латинской Америки. URL: https://scepsis.net/ library/id_2655.html 
4. Porter G. Reflections on a century of road transport developments in West Africa and their (gendered) impacts on the rural poor. URL: https://journals.openedition.org/ echogeo/pdf/13116.

5. Bonfatti, R., Poelhekke S. From Mine to Coast: Transport Infrastructure and the Direction of Trade in Developing Countries. URL: https://papers.ssrn.com/sol3/papers. cfm?abstract id $=2230307$.

6. Jedwab R., Kerby E., Moradi A. How colonial railroads defined Africa's economic geography. The long economic and political shadow of history. Volume 2. Africa and Asia. URL: https://www.sipotra.it/old/wp-content/uploads/2017/05/VolumeII.-Africa-and-Asia.pdf.

7. Abdussalam I. K. The role of rail and other transport systems in the colonial consolidation and exploitation in Central and Eastern Nigeria: 1897 - 1929. URL: https://www.academia.edu/1151826/the_role_of_rail_and_other_transport_systems in_the_colonial_consolidation_and_exploitation_in_central_and_eastern_nigeria_ 18971929.

8. Yusuf S.T. The socio-economic impact of the railway in Northern Nigeria : a study in transformation of the rural communities along the rail line between Kano and Zaria, 1908-1970s. URL: https://openaccess.leidenuniv.nl/bitstream/handle/1887/32000/01. pdf? sequence $=5$.

9. Obiakor N.J., Agajelu A.C. British colonial economic policies and infrastructure in Nigeria: the rail transport example, 1898-1960. URL: http://www.academix.ng/documents/papers/1479895362_3941.pdf.

10. Ngwenya B.N. The Development of Transport Infrastructure in the Bechuanaland Protectorate 1885-1966. URL: http://www.jstor.org/stable/40979716.

11. Acemoglu D., Robinson J.A. The economic impact of colonialism. The Long Economic and Political Shadow of History. Volume I. A Global View. URL: https://kellie-leeson.squarespace.com/assets/publications/2017/longshadow.pdf

12. Маркс К. Маркс - Даниельсону, 10 апреля 1879 г. / Карл Маркс, Фридрих Энгельс. Соч. 2-е изд. Т. 34. - М.: 1964

13. Андреев А.М., Кельчевская Н.Р. Борьба за минеральносырьевые ресурсы Африки: история и современное состояние. URL: https://cyberleninka.ru/article/n/ borba-za-mineralnosyrievye-resursy-afriki-istoriya-i-sovremennoe-sostoyanie/viewer.

14. Rodney W. How Europe Underdeveloped Africa. URL: http://en.bookfi.net/ book/1367525.

\section{Nikolaenko V. L., Kornilov V. S. Transport as a factor of construction and reproduction of spatial inequality}

The article highlights the problems associated with transport as a factor of construction and reproduction of spatial inequality.

The article shows:

- that sociology of transport cannot ignore the issue of spatial inequality and related issues;

- that the development of transport network is one of the factors of the transformation of geographical (physical) space into social;

- that transport network becomes a factor of the construction of a new (non-traditional) spatial inequality and its reproduction;

- that spatial inequality is an important factor of social control; 
- that there is a contradiction between the nationally-oriented transport infrastructure and transport infrastructure that is developed in accordance with the methods of colonial policy, because it distributes the flows of people and goods in accordance with the needs of the colonizers and so on.

It is important to note that transport is one of the factors linking space/time in people's lives. And since this connection is provided by technical means, its social dimension is not always clearly visible. However, when the speed and direction of movement of people and goods are considered from the point of view of market realities, it turns out that now they largely depend not so much on the cultural needs of the population but on the competition requirements when the desire to increase the speed of movement in the space covered with transport network becomes a means of gaining a competitive advantage.

Thus, the coverage of certain geographical areas by transport network is determined not by the abstract needs of the market, but by the needs of those socioeconomic entities that seek to minimize costs, often regardless of the possible social losses. It is not surprising, therefore, that, for example, in colonized countries, transport network has become one of the most important means of constructing and reproducing spatial inequality, while colonial policy issues are gradually disappearing from scientific and, in particular, sociological discourse in domestic sociology regardless of real practices of colonization of someone else's living space.

Key words: transport, sociology of transport, physical space, geographical space, social space, physical time, social time, social inequalities, colonial transport infrastructure, colonization of the lifeworld, transport colonialism. 